J. Fish. Sci. Tech. 5(1), 75 78, 2002

$\langle$ NOTE〉

\title{
Structural Alterations in the Gill of the Red Sea Bream, Pagrus major, Exposed to the Harmful Dinoflagellate Cochlodinium polykrikoides
}

\author{
Chang Sook Kim*, Bo-Young Jee ${ }^{1}$ and Heon Meen Bae \\ Harmful Algal Blooms Research Division and \\ 'Pathology Division, National Fisheries Research and Development Institute, \\ Busan 619-902, Korea
}

(Received January 2002, Accepted March 2002)

\begin{abstract}
The effects of Cochlodinium polykrikoides on the gill of red sea bream, Pagrus major, were examined to clarify the ichthyotoxic mechanisms of this plankton species. The gill of fish exposed to dense blooms over 3,000 cells $/ \mathrm{mL}$ for $24 \mathrm{~h}$ showed severe epithelial separation: a severe edema was found in the secondary lamellar epithelium and interlamellar regions of primary filament. In addition, lipid peroxidation of gill tissue in Cochlodinium-exposed fish was about 2.5 times higher than that of control. The composition of glycoproteins in the gill mucus of Cochlodinium-exposed fish was also changed. These results suggest that the loss of structural integrity of cell membranes in fish gill may be deeply involved in fish death by C. polykrikoides.
\end{abstract}

Key words: Cochlodinium poykrikoides, Fish death, Fish gill, Histological change, Red tide

Cochlodinium polykrikoides is one of the most frequently appearing harmful red tide dinoflagellates, which causes heavy damages to fish farming in Korea. The highest alleged economic loss was about US $\$ 95.5$ million in 1995 ( $\mathrm{Kim}$ et al., 1997). The lethal effects of this dinoflagellate on fish have been investigated to some extent (Onoue et al., 1985; Onoue and Nozawa, 1989a, b; Lee, 1996; Kim et al., 2001). Nevertheless, the precise ichthyotoxic mechanisms of Cochlodinium are still poorly understood. In our previous study, we have reported that reactive oxygen species (ROS) generated from Cochlodinium cells are one of causative factors inducing fish kill (Kim et al., 1999). In addition, the aspects of physiological and hematological changes in fish exposed to this algal blooms have also been investigated (Kim et al., 2000a, b). Particularly, inactivation of the ion-transporting enzymes such as carbonic anhydrase and $\mathrm{Na}^{+} / \mathrm{K}^{+}$-ATPase, and the drop

*Corresponding author: cskim@ nfrdi.re.kr of blood $\mathrm{PO}_{2}$ may play prominent roles in fish death caused by $C$. polykrikoides. On the basis of these results, it may be assumed that the structural alterations of gill cells are involved in fish death by C. polykrikoides. This study attempts to determine whether or not the loss of structural integrity of cell membranes of gill is associated with fish death by C. polykrikoides. For this, we examined the histological changes in the fish gill exposed to Cochlodinium blooms, and Cochlodinium-mediated histological responses were compared to those of fish killed by environmental hypoxia. In addition, the changes of polysaccharide composition in gill mucus and the lipid peroxidation of gill tissues of fish subjected to $C$. polykrikoides blooms were also examined.

The red tide dinoflagellate, C. polykrikoides, was collected in Namhae $\left(34^{\circ} 43^{\prime} 63^{\prime \prime} \mathrm{N}, 128^{\circ} 02^{\prime} 89^{\prime \prime} \mathrm{E}\right)$ during a bloom of the species in the summer 2000 in Korea. This algal bloom included a few Ceratium furca and Chaetoceros sp. $(<1 \%)$, respectively. The density of $C$. polykrikoides was monitored by 
counting the number of algal cells in $0.05 \sim 0.1 \mathrm{~mL}$ subsamples using a Sedgewick-Rafter chamber. The red sea bream Pagrus major (average $340 \mathrm{~g}$ in body weight, ca. $25 \mathrm{~cm}$ in total length) were purchased from an adjacent fish farm. Fish were transferred into tanks with continuous water supply, and acclimatized for 1 day. Five fish were exposed to algal cell densities of about $1,000,3,000,5,000$, and 10,000 cells $/ \mathrm{mL}$ for $24 \mathrm{~h}$ in $500 \mathrm{~L}$ tanks, respectively. The dinoflagellate was replenished every $6 \mathrm{~h}$ to the system to maintain densities. Test fish were also kept in natural seawater as control. During the experiments, the water temperature, salinity and dissolved oxygen in the containers were $23 \sim 24^{\circ} \mathrm{C}, 32 \sim 33 \%$ and ca. $5 \mathrm{ppm}$, respectively. In the case of experimental hypoxia, fish were kept under an anaerobic condition, in which was not bubbled with oxygen. Mucous solution was prepared by the method of Kobayashi et al. (1989) with a slight modification. The glycoproteins in the mucous solution were analyzed by sodium dodecyl sulfate-polyacrylamide gel electrophoresis (SDS-PAGE). The production of thiobarbituric acid-reactive substances (TBARS) from hot acid-digested gill tissues was monitored by absorbance change at $535 \mathrm{~nm}$ as an index of lipid peroxidation, as described by Buege and Aust (1978). For histological examinations, the fish gills were excised out from test fish and fixed in Bouin's solution. Paraffin sections were obtained by the conventional method, and then stained with hematoxylineosin (Endo et al., 1985).

When the test fish were exposed to $C$. polykrikoides of 1,000 cells $/ \mathrm{mL}$, they were kept silent throughout the exposure period, and didn't die. In contrast, the higher densities over 3,000 cells $/ \mathrm{mL}$ of algal species induced violent swimming. The red sea bream in seawater containing $C$. polykrikoides of 3,000 , 5,000 and 10,000 cells $/ \mathrm{mL}$ exhibited mortalities of about 30,70 and $100 \%$ in $24 \mathrm{~h}$, and the threshold in lethal time of fish was $9 \mathrm{~h}, 3 \mathrm{~h}$ and $1.2 \mathrm{~h}$, respectively. These results are similar to those of our previous study (Kim et al., 2000b).

To investigate structural alterations in the gill cells of Cochlodinium-exposed fish, we first compared the histological responses of lamellae and filaments. The gills of red sea bream exposed to dense blooms over 3,000 cells $/ \mathrm{mL}$ for $24 \mathrm{~h}$, moribund and dead fish, showed severe epithelial sepa- ration: a severe edema was observed in the secondary lamellar epithelium and interlamellar regions of primary filaments (Fig. 1). Moreover, the membrane swelling and/or lysis were found to be out of all proportion to the level of algal cells and exposure time. The swellig or lysis of gill membrane by C. polykrikoides are very similar to those observed in the fishes exposed to Chattonella (Endo et al., 1985; Toyoshima et al., 1985). Meanwhile, interestingly, the histological alteration in the gills of killed fish caused by environmental hypoxia was different from those of Cochlodinium-exposed fish; lamellar epithelium was contracted (Fig. 1D). The histological changes by a harmful algal cells were different from those by environmental hypoxia, which indicates that some substances containing chemical and/or physical stimuli are associated with fish death by $C$. polykrikoides.

Coomassie blue-stained SDS-PAGE profiles indicated that the composition of glycoproteins in the gill mucus of Cochlodinium-exposed fish was changed; some proteins were degraded, but one protein was increased (data not shown). These phenomena are also similar to those observed in yellowtail Seriola quinqueradiata exposed to Chattonella sp. (Kobayashi et al., 1989). Although the precise mechanisms of the compositional changes of glycoproteins during red tide exposure are still poorly understood, they proposed that these changes were involved in the capability of the gill epithelium to exchange gas. Thus, it is also assumed that this change is related to the gas exchange on the surface of the gill in Cochlodinium-exposed fish, as in Chattonella sp. In addition, lipid peroxidation of gill tissue was also found in $C$. polykrikoides-exposed fish as compared with the control fish: the values of TBARS averaged $18.2 \pm 1.3,40.5 \pm 4.1$ and $46.4 \pm 5.6$ $\mathrm{nmol} / \mathrm{g}$ tissue in control, moribund and dead fish, respectively. Lipid peroxidation has been linked to the increased solute permeability of the membrane, which is directly connected to the swelling and lysis of membrane vesicles, as observed in liposome (Girotti, 1990). Thus, we can guess that, at least to a certain extent, lipid peroxidation is involved in the loss of structural integrity of cell membranes of fish gills, as we previously reported that ROS generated from $C$. polykrikoides induced lipid peroxidation of gill cells (Kim et al., 1999). Moreover, 


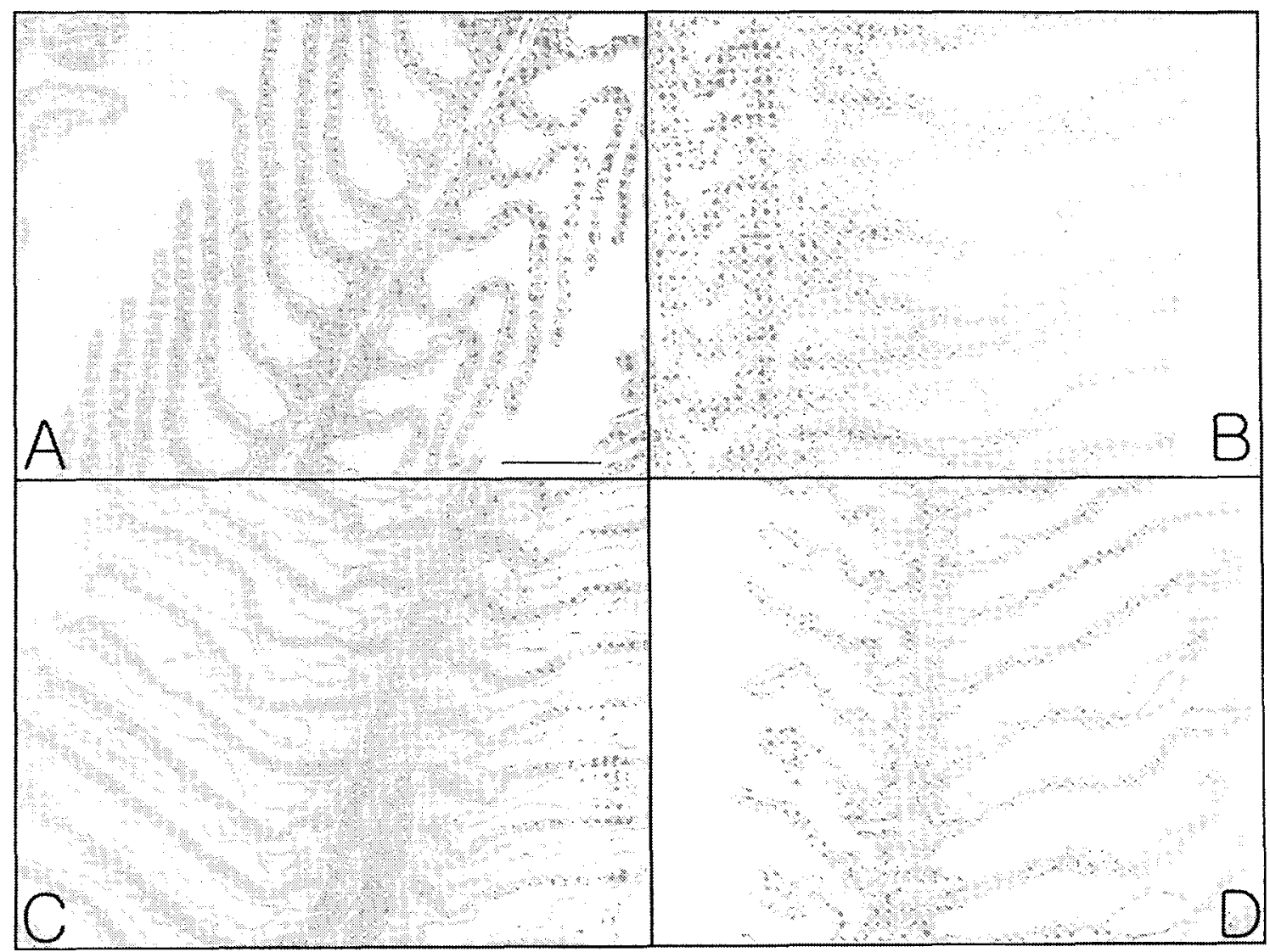

Fig. 1. Histological changes of gill filament of the red sea bream exposed to $C$. polykrikoides. A; control, B; moribund fish, C; dead fish, D; dead fish by environmental hypoxia. The moribund fish were still alive but showing the symptoms including loss of equilibrium, swimming on side or upside down and grasping for breath. Bar represents $50 \mu \mathrm{m}$.

these structural disturbances seem to some extent to be involved in functional changes such as inactivation of ion-transporting enzymes, which in turn is responsible for inhibiting gas exchange in fish gills.

If it is so, what are the causative agents inducing structural disturbances in Cochlodinium-exposed fish? In this respect, with first priority, we can guess that the ROS generated from algal cells is one of the factors inducing membrane alteration. Since oxidative damages such as oxidation of lipid and protein in gill cells are induced by ROS, these damages may be associated with the edema and/or lysis of cell membrane. Meanwhile, some workers have reported that the swelling of the pavement cells in fish gill was occurred by heavy metals and various toxins existed in algal cells (Hart and Oglesby, 1979; Endo et al., 1985). Thus, the possi- bility would not be entirely excluded that certain substances present in algal cells may also be involved in the loss of membrane integrity. Further study is currently underway in our laboratory.

In conclusion, our results indicate that the loss of structural integrity of cell membranes in fish gill exposed to $C$. polykrikoides seem to be involved in decrease of gas exchange in the gills. What we can guess from this finding is that the gill of fish subjected to $C$. polykrikoides could be damaged, eg. the loss of functional and structural integrity of cell membranes, by some factors containing ROS.

\section{References}

Buege, J.A. and S.D. Aust. 1978. Microsomal lipid peroxidation. Methods Enzymol., 52, 302 310.

Endo, M., T. Sakai and A. Kuroki. 1985. Histological and his- 
tochemical changes in the gills of the yellowtail Seriola quinqueradiata exposed to the raphidphycean flagellate Chattonella marina. Mar. Biol., 87, 193 197.

Girotti, A.W. 1990. Photodynamic lipid peroxidation in biological systems. Photochem. Photobiol., 51, 497 509 .

Hart, P.K. and G.B. Oglesby. 1979. Toxin induced changes in the gill epithelium of rainbow trout (Salmo gairdneri). Scanning Electron Micros., 197, 355 361.

Kim, C.S., H.M. Bae, S.J. Yun, Y.C. Cho and H.G. Kim. 2000a. Ichthyotoxicity of a harmful dinoflagellate Cochlodinium polykrikoides: Aspect of hematological responses of fish exposed to algal blooms. Kor. J. Fish. Sci. Tech., 3, $111 \sim 117$.

Kim, C.S., S.G. Lee, C.K. Lee, H.G. Kim and J. Jung. 1999. Reactive oxygen species as causative agents in the ichthyotoxicity of the red tide dinoflagellate Cochlodinium polykrikoides. J. Plankton Res., 21, 2105 2115.

Kim, C.S., S.G. Lee and H.G. Kim. 2000b. Biochemical responses of fish exposed to a harmful dinoflagellate Cochlodinium polykrikoides. J. Exp. Mar. Biol. Eco., 254, $131 \sim 141$.

Kim, C.S., S.G. Lee, H.K. Kim and J.S. Lee. 2001. Screening for toxic compounds in the red tide dinoflagellate Cochlodinium polykrikoides: Is it toxic Plankton?. Algae, 16, $457 \sim 462$.

Kim, H.G., S.G. Lee and K.H. An. 1997. Recent red tides in Korean coastal waters. Nat. Fish. Res. Dev. Agency., pp.
237 239 (in Korean).

Kobayashi, H., Y. Takahashi and T. Itami. 1989. Changes in the electrophoretic pattern of mucous solution extracted from gills of the yellowtail Seriola quinqueradiata affected by the red tide. Nippon Suisan Gakkaishi, 55, 577.

Lee, J.S. 1996. Bioactive components from red tide plankton, Cochlodinium polykrikoides. J. Kor. Fish. Soc., 29, 165 173 (in Korean).

Onoue, Y., K. Nozawa, K. Kumanda, K. Takeda and T. Aramaki. 1985. Toxicity of Cochlodinium type 78 Yatsushiro occurring in Yatsushiro Sea. Bull. Jap. Soc. Sci. Fish., 51, 147.

Onoue, Y. and K. Nozawa, 1989a. Zinc-bound PSP toxins separated from Cochlodinium red tide. In Mycotoxin and Phycotoxins 88', S. Natori, K. Hashimoto and Y. Ueno, ed. Elsevier, Amsterdam, pp. 359 366.

Onoue, Y. and K. Nozawa. 1989b. Separation of toxins from harmful red tides occurring along the coast of Kagoshima prefecture. In Red Tides: Biology, Environmental Science, and Toxicology, T. Okaichi, D.M. Anderson and T. Nemoto, eds. Elsevier, New York, pp. 371 374.

Toyoshima, T., H.S. Ozaki, M. Shimada, T. Okaichi and T.H. Murakami. 1985. Ultrastructural alterations on chloride cells of the yellowtail Seriola quinqueradiata, following exposure to the red tide species Chattonella antiqua. Mar. Biol., 88, 101 108. 